\title{
ON BORDERS: FROM ANCIENT TO POSTMODERN TIMES
}

\author{
Giuliano Bellezza \\ Giuliano Bellezza, Universities La Sapienza (Rome), and Tuscia (Viterbo) \\ Via di Brava 121, 00163 Roma, Italy - giuliano.bellezza@uniroma1.it
}

KEY WORDS: Borders evolution in History, Type of borders, Frontier Turner's concept, Borders in Modern States, Human and Cultural borders, Postmodern thoughts on borders, Virtual cyberspace borders

\begin{abstract}
:
The article deals with the evolution of the concept of borders between human groups and with its slow evolution from the initial no men's land zones to the ideal single-dimension linear borders. In ancient times the first borders were natural, such as mountain ranges or large rivers until, with the development of Geodesy, astronomical borders based on meridians and parallels became a favourite natural base. Actually, Modern States adopted these to fix limits in unknown conquered territories. The postmodern thought led give more importance to cultural borders until, in the most recent times, is becoming rather impossible to fix borders in the virtual cyberspace.
\end{abstract}

\section{BEGINNING OF AN EVOLUTION, FROM NO MEN'S LAND TO FIXED BORDERS}

Once upon a time, the first communities of hunters-gatherers used to protect their territories, without materially marking definite limits; instead, between hostile tribes there were broad no men's land, namely wide respect areas. Everybody knew that entering too much in the no man's land, hence approaching the settlements of the "others", could be not only dangerous, but even deadly. In the course of time the broad areas tended to become thinner and thinner. This didn't exclude contacts and trades; there were particular exchange areas, where one tribe uses to leave on the ground some commodity. The neighbouring tribe arrives shortly, looks and if interested leaves other products of similar value. Then the first tribe comes again: if satisfied accepts the exchange and takes the products, if not simply takes back his first offer. An exchange, but not a friendly one.

The human organisations, developing, from groups of families, clans, fortified settlements, kingdoms and empires have always been more determined about the delimitations of the controlled territory, the final goal being a material divisor alignment. The platonic ideal limit is a simple line, with only one dimension, the length; but this should necessarily be marked in the ground by scattered milestones: it took thousands of years to begin to see the first real material attempts of delimitation.

In the ancient times, the main attempt to transform a frontier region in a linear border have been, as early of 7 th Century BC, the first sections of what later became the Emperor QinShi's Great Wall, with progressive additions in the following centuries. In the western world the first steady fortified alignments to identify a border were activity of the Roman Empire, but in a different way. Maybe because of my very traditional Geography formation, I use to see differences as influenced by the environment. The area of the no men's land between Chinese Empire and nomadic Mongol tribes and peoples was mainly semi desert: to arrive from a wide frontier region to a limited, linear one the Empire could only build a material boundary: the Great Wall slowly grew for a millennium, to become the major men built opera ever. With the last additions under the Ming Dynasty, a total length of more than $21,000 \mathrm{~km}$ is calculated.
The Roman power began to materialise the limit of its territory only after the Empire was established ( $27 \mathrm{BC}$ ). Since the Republican time the Roman conquered territories beyond the Alps, and the Empire, of course, wanted to enlarge much more the conquests. The central European environment was covered by wide, dark forests, inhabited by wolves, bears and, above all, fierce German tribes: regions very difficult to invade, where the building of walls was nearly impossible. It has been a long endeavour, called Roman Limes, the Latin limes clearly being the stem word of limit in modern languages (not only NeoLatin). The best divisor element supplied by nature was the rivers: in fact, the Roman expansion in today Germany proceeded along the left (western) bank of the Rhine and the right (southern) bank of the Danube. Slightly different has been for the Romans the invasion of Great Britain, until the northernmost part, inhabited by the indomitable Caledonian Celtic tribes (and really very far from Rome). This region was not totally forested, so the building of a wall has been convenient, but possible only in the second Century AD. Let me stress that History, as well as Geography, must take in account the environment.

The nearly $120 \mathrm{~km}$ of the Hadrian's Wall have been constructed in 122-128 A.D., from the mouth of Tyne River (West) and the Solvay Firth (East), indicating the Limes Britannicus. 20 years later, the Antonin's Wall was constructed, some $150 \mathrm{~km}$ more north, between the Firth of Clyde (West) and the Firth of Forth (East), with a length of about $63 \mathrm{~km}$. About 40 years later the Antonine wall was nearly abandoned, leaving a sort of no-menland between the 2 fortified lines.

\section{LIMITS: FROM PHYSICAL-NATURAL TO HUMAN- HISTORICAL-ASTRONOMICAL, AND THE FRONTIER CONCEPT}

The physical or natural borders have already been mentioned speaking about the Roman Limes, quoting mountains (the Alps) and rivers (Rhine, Danube): the best definite border for a region is the sea coast, and no region can be best defined then an island (don't forget these words, only goods for physical geography: limit of territorial waters are very difficult things). Geographers mainly discuss in terms of territoriality and sovereignty, seeing boundaries as expressions or manifestations 


\section{5 - 6 December 2013, Beijing, China}

of the territoriality of states, and this can be true today, but in the ancient time the confrontation opposed first strong organisation against poorly organised tribes. So, we arrive to the category of historical (or artificial) boundaries. Here we include all the cases when two human entities (in that time just one) decided to consider a particular line as limit to their sovereignty. Only recently the discussion has been on a nearly peer-to-peer basis, but even now, at the end of a war, there are strong controversies, unless the loser had been forced to a capitulation with no conditions. Commonly, until the contemporary era, at the end of a war, the winner was simply swallowing the loser's territory.

A situation appropriately expressed by the North-American situation after the civil war, when none was discussing USA sovereignty from Atlantic to Pacific; but west of Mississippi there were: millions square $\mathrm{km}$ of unsettled areas: the wilderness. US Government had no knowledge at all on territory and existence of native populations, above all about the number of these. In the ' $90 \mathrm{~s}$, Frederick Turner, relating to this area, exposed his concept of American Frontier. All western territories were to be no longer considered as no men's land, but as a region to be tamed, settled and civilized, to be really included under the hegemony of the new American white dominators. The Frontier was the mobile line the pioneers should continuously push forward, until the final border that is the Pacific coast. Winning liberty against European colonisation one Century before, Americans had demonstrated to be unique, exceptional people, bound to dominate the continent by an evident manifest destiny. In the following Century, US citizen's common sentiment was structured in this direction by nearly all the history and geography teachers of US, in agreement with Turner's thought. In the 20th Century, especially after WW2, the frontier concept has been extended to the whole planet: in other word, there is a strong belief that the manifest destiny pushes the world history toward a US primacy, not only military or economic, but also cultural.

At government level, a new concept of Frontier was called in the ' 30 s by F.D. Roosevelt, asking the people to fight a common battle: the new frontier to conquest was now the recovery of national economy from the 1929 crisis. In a few years of New Deal, with direct State intervention under M. Keynes' principles of economy, the situation showed steady improvements.

In 1961, after the success of URSS, launching Yuri Gagarin as first men in the space, John F. Kennedy invoked Turner's idea, transferring the new Frontier in the outer space: it took only 8 year to win the battle, sending in 1969 the first expedition to the moon. .

\section{ASTRONOMICAL LIMITS ARE VERY COMMON}

The fantastic improvement of the scientific instruments during the XVIII Century in Europe allowed the States to establish really linear boundaries. Many or the European ones were historically established since Centuries, especially when facilitated by natural limits as mountains' ridges or wide rivers: in these cases the material problem was the disposition of the signals.

The situation was quite different in North America, where the limits imposed by the English Crown, to the Colonies were based on Meridians and Parallels. We call these boundaries, surely historical, in a category called antecedent, meaning that they were decided before a real human settlement. After the United States independence and the following acquisitions, there were millions square $\mathrm{km}$ of unknown wilderness. President Jefferson established the "grid system", de facto following the solution adopted by the English Crown, based on the geographic coordinate system. But Jefferson decided to start with measures taken in the field. The first experimental result was the Mason-Dixon Line between Maryland and Pennsylvania (USA): the first really linear boundary, with markers (milestones) every mile, and special Crownstones every 5 miles.

I wouldn't call artificial this kind of limits (and even less, as somebody does, virtual) because Meridians and Parallels are undoubtedly intangible, but the Poles, the Equator and the Tropics are real, existing features of the planet. When measured on our time-scale, they can be taken as stabled, and so is the geographic system based on their position.

With no knowledge at all of the immense area being divided, the Jefferson's idea was as simple as efficient. The Federal Cadastre was incredibly simple and already available in the Land Registry in Washington before the pioneers could began to take possess of the western territories. Their new possession were recognised only within the limits of the Survey Townships, based on squares with 6 miles sides, divided in 36 sections of 1 mile. Only very little fees were paid, but the property (of 1 section or of a quarter section) should coincide with an existent partition in the Federal Land Registry in Washington. No diversion to include a water spring or avoid bad land or rocky soils were admitted: one could only pay to add a better conterminous section, and Federal Government would protect his property.

This kind of blind imposed limits was based on a very unfair principle: no consideration at all for the indigenous peoples. The today American Indians were called in that time only as uncivilized tribes: they were forced to migrate westbound, along road-less territories, on what have been later called trails of tears. Only later some areas have been destined as reserves, where American Indians could follow their uses (only if not colliding with US laws, indeed). American Indians revenue today is by far less than the mean US' one, but Government answers that Indians are more today than at the end of XIX Century (impolite asking how many they were before 1800).

An even more shameful system has been adopted by the European Powers to colonize Africa, and consequences have been even more awful, because in this case the wilderness was mpre populated. After a period called Scramble for Africa, the European states laying claims on the Continent gathered in Berlin (1884-85), and agreed to politically divide the Continent in spheres of influence. The limits of the spheres were fixed on the maps and as fast as possible materially fixed on the ground, with no consideration to the local divisions between tribes and cultures. Don't forget, on the other hand, that European considered African population poorly civilised, if at all: to the point that Africans had simply been used, in the previous Centuries, only as the best and convenient energy resource for the needs of the American agriculture.

Astronomical borders have a great advantage: they really are fixed, insensitive to earthquakes, floods or erosion and several times have been changed and adapted to the advantage of the conterminous States, with mutual agreements.

But we must now introduce some geometrical considerations. A geographical limit has been defined as a one-dimensional sign on earth surface: a line whose only dimension is the length, with no width. Only ideal abstract definition, as the idea must be forcibly realised on earth: this means that we can't ignore the third dimension.

In agriculture the owner of a title of property has no restriction to dig some meters to find water, but things become different when there is some underground mineral wealth. Only some States guarantees to the owner the right on the hidden resources, 


\section{5 - 6 December 2013, Beijing, China}

while in the older European States the owning right is limited to the surface (being understood the right of digging a water well). Nearby Rome there are huge deposits of travertine stone, but to dig it one must pay an exploiting license to the State.

Big difference from the lucky persons who digging for water in some parts of USA, could unexpectedly find oil. In this case, the property ideally extends from a point on the ground down to the centre of the planet.

\section{MODERN STATE CONCEPT: RATZEL, HAUSHOFER, ANCEL}

At the end of $19^{\text {th }}$ Century, Friederich Ratzel, the founder of the Political Geography, wrote that a State is qualified by the contemporary existence of three features: a piece of land where a population lives and recognise a sovereignty. Interested in Darwin's theory of evolution, he asserted that every State should constantly push to enlarge its vital space, to the point that the competition with conterminous States is obliged (all having the same need). This being the situation, as soon as a new State is born, it is obliged to struggle, because growing by conquering new space is crucial to survive; if not, a State will be beaten by a more powerful one, and dye. In Ratzel's vision, the environment was exerting a strong influence on the human history, and his thought received by many geographers and historian an exaggerated adhesion. Still today, many see Ratzel as champion of a total environmental determinism, while his fundamental book Anthropogeographie is not naive or simple, indeed. He was well aware that in the same environment, i.e. Egypt, at the moment nearly colonised by United Kingdom, and previously dominated by Muslims, Romans, Greeks, in ancient time had been the major Empire of the Mediterranean area, for thousands of years.

In 1904 Halford Mackinder drew a map, identifying a Heartland: the State possessing the Heartland will fatally dominate the world. Of course, Mackinder was writing some years before the first flights of the Wright brothers, when only an ocean competition with USA could be considered a peril for Eurasia. But his real nightmare was that Russia, enjoying the possession of the Heartland, could dominate the world. Mackinder opinion enforced after the revolution, later with the air and rockets warfare, eventually with the atomic terror. After WW1, Isaiah Bowman, foreign policy advisor for US Governments from ' $30 \mathrm{~s}$ to ' $50 \mathrm{~s}$, envisaged a world dominated by US, thanks to air warfare; following has been the vision of a future world in permanent "terror peace", dominated by intercontinental rockets with atomic weapons, and no possible boundaries but the hope in spatial shields.

In reality, the worst development of Ratzel's evolutionary theory adapted to the State history had arrived long time before, soon after WW 1, when the German official Karl Haushofer founded the Geopolitics. Contrary to the general belief, he was not really Nazi: he did only go further on along the evolutionary theory about the State development. Merging all the extreme idea about the State development with Haushofer's, Hitler enthusiastically found the way to convince the German people to follow his project: wherever somebody speaks German, said Hitler, there arrives the legitimate German vital space. With continuing propaganda on this premises, the $3^{\text {rd }}$ Reich population felt morally obliged to conquer all the territories until the lower course of river Volga.

This has been a very unlucky outcome of Haushofer theory, while his definition of borders, shared by the French Geographer Jacques Ancel, is interesting: all boundaries are no more than temporary lines and political isobars that continually undergo change, as a result of conflict, military expansionism and territorial conquest. Due to my origin as graduate in Geology and Natural Sciences, I very much like the expression political isobars.

Some lines above I wrote that borders based on the Geographical Coordinate System are not only natural and human at the same time, but they can also be easily changed. Concluding this paragraph mainly dedicated to war discourse, I like to quote a couple of peaceful events.

When USA and United Kingdom wanted to fix the border along the parallel $48^{\circ}$ North, in 1818 each one ceded to the counterpart some territories, instead of spending lot of time, discussing for a still unpopulated land. In South America, Bolivia and Argentina agreed to fix many km of boundary on the parallel $22^{\circ}$ south; after, measuring in the field, the topographers discovered that in so doing the Bolivian city named Yacuiba would have become Argentinian. In 1925, the Governments again had a peaceful discussion, and the straight line was slightly modified. May peace prevail on earth.

\section{HUMAN AND CULTURAL BORDERS}

Nowadays, we can say that all the definite borders are human, as result of human agreements, even when one counterpart had been obliged to accept it. In $20^{\text {th }}$ Century everything became more diplomatic, but still in a crossing place of a mountain range, the winner will not be happy exactly on the watershed: he will take it all, reserving the highest tract of the road on both sides. Along a river he will take not only half of a bridge, but will impose a stronghold on the enemy's bank: exactly what Romans did on Rhine and Danube. Moreover, the section of human borders is much more complicated than the natural, physical ones, due to the uniqueness of the human minds and cultures, joint with the relentless human instinct to move.

One of the first tasks of the URSS Constitution was the administrative division of the immense territory, assigning to each people their inhabited land: this saved dozens of peoples and languages, creating nearly incredible situations in the less populated regions. To quote but a few, the Republic of Saha (better known as Jakutiya) with territory measuring more than 3 million square $\mathrm{km}$, where less than 1 million inhabitants live; the Autonomous Okrug (District) of Evenky, with more than 760,000 square $\mathrm{km}$ and hosting a slowly growing population of 16,200 peoples. Surely, during the nearly 100 years passed ever since, there has been Russian immigration for mining industry, but not much: region is not attractive at all, mainly because the climate on these mines is the coldest of the northern hemisphere, and workers had to be lured with salaries much higher than in Europe.

Things are different in more densely populated areas, where territory possession is more valuable, as we can see in the northeastern region of Italy, limited by international borders with Austria, Slovenia and Croatia. Only 3, because the Furlan, settled on both sides between Italy and Austria, and the Ladini, settled on both sides between Italy and Slovenia, didn't yet achieve Independency. Establishing a real limit is impossible, as the representatives of the different ethnics are dispersed and mingled everywhere, with their own languages, not to mention religions: independent from the ethnic, a Christian family can follow Catholic, Orthodox (Greek or Serbian) or Lutheran rites, and of course Hebrew and Muslim also are there. Toponyms are often bilingual, if not trilingual. A sharp human limit can only be found when environment provides it, in form of a high and long mountain range, or a wide river difficult to cross, but in these cases also, when populated on both sides since ancient time, some mixture did surely happen. It's reasonable to define subsequent this category of boundaries. 


\section{5 - 6 December 2013, Beijing, China}

I report just an example of religious borders, and the attempts to find a solution in Europe, in the $16^{\text {th }}$ and 17 th Centuries. The Holy Roman Empire was shocked by the Protestant Reformation, based on Luther's 99 Theses (1517). After a series of wars, the Augsburg Peace (1555) decided that all the Kings and Princes of Central Europe could adhere to Protestantism (but only Lutheran confession, not Calvinist or other). To avoid confusion, it has been decided that, all the citizens of a territory should forcibly follow their sovereign's religion. The Latin synthetic expression summarising the decision was cuius regio eius religio, to be translated as your region, your religion. Useless to say that again wars followed for dozens of years, until the Peace of Westphalia (1648): here many European States participated, just as States, independent from their religion. The cuius regio eius religio principle still remained at large, with the inclusion of Calvinism, and the strong opposition of the Pope was taken into little consideration: the Roman Catholic States didn't accept a total Vatican subjection in religious matter. It can be said that the Modern State, close to some Church, but not dependent from it, was taking form.

Just a few years later, a strong development of measuring instruments for geodesy, topography and cartography happened: these disciplines were still part of the Geography, ad all the involved persons were Geographers. Since the antiquity, cartographic activity has not been totally neutral: maps were very useful, strategic tools. In $17^{\text {th }}$ Century maps began to be drawn with a purpose, and somebody spoke of two different categories, dividing the State or King geographers from the natural or pure ones. In $18^{\text {th }}$ Century, maps drawn by the first were legitimating the State possessions of some territories, so becoming instrument of domination. They were equating power with things and in the same time equating things with power, thus normalizing it. Pure geographers, instead, didn't care of politic or administrative limits, dividing the Earth only following natural features: in some way, they were criticising the existent power, based on the heritage of feudal and aristocratic period, thus legitimating the growing class of bourgeoisie. Some decades later Ratzel would write that a State can only exists if its population recognize sovereignty and really possesses a territory, clearly delimitated by sure boundaries: and so we arrive to contemporary time.

\section{POSTMODERN THOUGHTS AND NEW RELATIONS WITH OTHER DISCIPLINES}

People more active and willing to innovate have been present in the human communities along the whole history. In the second half of XIX Century, when Western Science was less influenced by religion, the Vatican began to call "modernity" the new innovative attitude. A hundred years later the grandsons of modernity speak in terms of "postmodernity", usually shorted in postmodern. Innovators' intents have always been similar: criticism of whatever has been done before, new methods of research, new fields of studies, freedom of mind-sets and, especially in this case, necessity of overcome the bottlenecks of modernistic rationality. As it always happens, in the renewing movements some beginners adhere too much, nearly arriving to exclude rationality: in my opinion, many postmodernists feel happy in adopting some kind of deregulation, in the ' 80 s and '90s so in fashion in politics and economy.

A positive effect of postmodern in Geography has been the more close relation with human disciplines like sociology, psychology, architecture and others: all disciplines leaving wide possibilities to personal interpretations. On the other hand, this too often led to forget the importance of environment; because where natural science is involved the field of personal interpretation is narrowed. Consequently, many postmodernists willing to fight the scientific mainstream and the official academy, both considered as submitted to economic power, give uncritically adhesions to catastrophic environmentalism theories, though often exposed in poor scientific terms.

Sociology and psychology jointly say that the observer unavoidably modifies the conditions of the observed (whether living or not); moreover, given that every brain observes in personal way, it is normal that two observer see reality in a different way. This can lead from the Cartesian "cogito ergo sum" (I think, than I am existing) to what I like to call the postmodern "cogito, ergo est" (I think, than reality exists). In other words, one can arrive to think that there are as many Geographies as human beings.

In the discussion on borders, we shall remember that in Anthropology a boundary means the socio-spatial constructed difference between cultures and categories and a border generally stands for a line demarcated in space. Postmodern usually neglects the natural part, stating that the right border is where the bordering communities like to fix it, somehow seconding Anthropology. Surely, geographical studies on borders had a shift in the last decades: the focus once given on political limits of states is now given to borders as socioterritorial constructs. But this seems to ignore an (ironically) anthropological reality: desires are not the same, rather there are differences not only between on the different sides of the border, but in the same communities as well. All in all, if the border is a social daily updating construction, it is easy to understand that this concept will never be translated in a defined limit, least of all in a definitive one.

In this confrontation, Geography should insert the spatial dimension more explicitly back into the discussion of these phenomena. On the other hand, we became more aware of the multidimensional nature of boundary studies: this means that we are facing the necessity of more detailed examination of the impacts of trans-boundary migrations externalities, like creation of exclusive and inclusive group identities. We shall not forget the ecological safeguarding problems tied to trans-boundary pollution, not to mention the protection of migratory animal species; in the oceans this includes also non migratory species, and large fishing boats are depleting a unique source of high quality food.

The good influence with other disciplines influence led J.P.Sharp (1993) to state that Geography, as an act of knowledge, is 'creative of the world, and not simply reflective of it'. Elena Dell'Agnese, today Chair of the IGU Commission on Political Geography, translated this in her article Geographing: Writing World. Things being so, Geography remains as a discipline qualified to describe the world, but is also proposed as the best fit for any kind of planning: population redistribution, environmental impact assessment, changes of regional economy and so on. Interesting see that the first article of NGM, October 2013 title is "Photo Power, cameras have changed the world in which we live", by Robert Draper.

Of course, scope and destination of Geographical Research are always my main interest. Some years ago, in the ' $60 \mathrm{~s}$ and ' $70 \mathrm{~s}$, the so said Quantitative Revolution immediately had an opposition by the older academicians, and soon after a much serious one by Critical Geographers, as they were revitalising in political terms an old argument about State and Nature geographers. The question was posed now in terms of: why are new technics used to serve the existing development model, and not to oppose it? The excessively quantitative scholars were qualified as Geographers now at the service not of a King, but of the economic power. 


\section{5 - 6 December 2013, Beijing, China}

Not surprisingly, in that time Yves Lacoste's book " $\mathrm{La}$ Géographie serve d'abord pour faire la guerre" was published, with academic scandal. Actually, the same Lacoste had just demonstrated that Geography is a useful tool to make peace (in Vietnam). Academics and conservatives were scandalised because a scholar dared to state a tri-partition of Geography: the boring one, used in School teaching, the spectacular one, showing natural life and beautiful landscapes in cinema and TV and the real, scientific, useful one, used only by Governments and Armies in all countries, for their scopes (survival of the fittest State, in Darwin-Ratzel terminology). Spectacular and boring ones were only destined to present Geography as a useless discipline. As far as I am seeing nearly everywhere in the world, Geography school teachers are, but a few exceptions, rather desperate because of the unconcerned attitude of their students.

\section{END OF THE HISTORY AND NEW BORDERLESS WORLD: AND SO, WHY SO MANY NEW WALLS?}

Between the ' 80 s and the ' 90 s a sociologist and philosopher of evident Japanese origin, F. Fukuyama, exposed a hypothesis about the end of history, immediately gaining worldwide resonance. Contributor to the right conservative Reagan's Doctrine, he thought that, with the end of the Cold War, the world evolution was teleological directed toward a global unified liberal democracy, under the free market rules. The destruction of the Berlin wall reinforced his opinion and soon arrived the end of Soviet Union and the multiplication of new independent States. All of these demonstrated to be very jealous of respective borders, and ready to fight to save them. These events were a clear evidence that, in the next time, boundaries would have been multiplying rather than diminishing. So it appears rather incomprehensible the tendency of many postmodern scholars to continue writing in terms of a future disappearing of boundaries.

Z. Mlinar (1992) wrote that in the new postmodern thought was included the transformation of socio-spatial organization. This transformation would have been accompanied by the loss of boundaries, while in the same time the globalization processes would have been threatening the particularity of places, borders, and territoriality. Mlinar, probably, didn't realize that all this was implying the end of Geography, but added that his forecast would have soon begun to happen into a postmodern "hyperspace": an expression needing a more detailed definition, I think. As a side effect, many postmodern thinkers criticise all kind of attempt to represent reality, with a sort of refusal of any kind of cartography.

I wonder whether these theories had been somehow influenced by a wrong interpretation of Fukuyama's end of history hypothesis, moreover transferred in the Mc Luhan's global village. In any event, when D. Newman and H. Paasi (1998) reviewed from various academic fields the postmodern literature on boundaries, they identified four major themes, and the first of them was the suggested disappearance of boundaries. To confirm Newman and Paasi's assertion, one could look for Allen and Hammet (1995), Kuehls (1996), Shapiro and Halker (1996). But the majority of the vast production has a good standard, and a lot of observations deserve to be taken in consideration, the same Authors wrote, and notions as separate spaces and single national identities should have the same emphasis of shared spaces and multi-identities. Actually, the second major theme identified by Newman and Paasi was the role of boundaries in the construction of socio-spatial identities. In the globalisation process the "space of flows" is rising, while the "space of places" is shrinking (M. Castells, 1989) but T.K.
Oommen (1995), wrote "even when old, existing boundaries are perpetually contested and desacralized, new boundaries are concomitantly recreated and sacralised again".

The problem I want to stress now recalls the argument dealt with at the beginning. There is an always growing of migration from poor to wealthy countries, and a parallel enforcing of the policies to strengthen the borders. The solution for this is the same adopted in the ancient times: the building of walls. The most famous after the $2^{\text {nd }} \mathrm{WW}$ has surely been the Berlin Wall, then the Jerusalem one took first place in the press; what is really blameworthy in this case is the unreasonable partition of the West Bank. Quite unperceived remained the wall built by South Korea near the boundary with North Korea, in despite of the millions ton of concrete utilized. One more wall, not adequately known and not metaphoric at all, is the one built by USA along the Mexican border.

Yet, the most dramatic obstacle to desperate human migration today is not an artificial construction: moats filled with water were good defence for castles, and today Europe is defended by African migrations by the wider possible moat, the Mediterranean Sea. Seen from Libya or Tunisia, Italy is a sort of half lifted drawbridge: thousands of men, women, some of them pregnant, toddlers, boys and girls try to reach the half lowered bridge: who doesn't succeed will just drown in the sea. Usually the boats arriving in the Italian territorial water are damaged, and shall be rescued by the coast guard: from this moment, the responsibility is only Italian. There is a really striking difference between the human assistance the refugees receive in the small island of Lampedusa (30 square $\mathrm{km}$ and about 7,000 inhabitants) and the indifferent reaction of the selfish, wealthiest countries of Europe, still reluctant to give some substantial help, though Italy is a founding member of the European Union.

In fact, the question of sea borders and territorial waters became more and more complex during the history. Some Centuries ago it was rather simple: a boat could navigate freely, until arriving to the range of coastal guns. Later, to protect the rights of the fishermen's, the limits were extended to 6 or 12 miles from the coast line, until the third dimension has been considered: the limit should extend to a given depth, or shall include the whole continental shelf? Everything had been complicated with the possibility to exploit resources offshore: the question should be mentioned in our workshop, but is a theme for diplomatic discussions. Instead, I wrote the last lines just because the Italian coast guard not only save the refugees in the Italian waters, but also rescue shipwrecked in the international ones, with the strong opposition of the right wing parties in the Parliament.

\section{CYBERSPACE: FACILITIES AND PROHIBITIONS}

For dozens of year the cyberspace communicating facilities has been taken as a progress for all, explaining the success of the "global village" expression in the " 60 s. In this new age, wrote Mc Luhan, humankind will move from individualism and fragmentation to a collective identity, with a "tribal base." Very rarely, I admit, I agree with sociologists in their geographical assertions, and my critic to this expression is simple: in the real tribal-based village life, everybody is in friendly relation with everybody. The help is immediate, when someone falls from a tree or when a woman is having a son. In fact, when the cold war ended, there were red-lines to allow USA and URSS Presidents to immediately establish direct contact. Very nice indeed, but in the $3^{\text {rd }}$ World lot of people still didn't know the existence of the telephones. And today there is not a world war, but red hot local wars are fought in many places, often on a not 


\section{5 - 6 December 2013, Beijing, China}

so local scale. I honestly want to point out also that McLuhan used the word "village" in his metaphor with a particular meaning, moving from his firm belief that the development of communication had extended our senses to include all the world: only in this acceptation, and restricted to developed countries, the today world can be intended as a village. But, I repeat, our village is all but a peaceful one.

Boundaries are our first interest in this workshop, and taking the words of M. Castells (1996), globalisation is unexpectedly marked by strong polarisation: every global city is a sort of black hole of marginalisation and exclusion from the global network society. The development of cities to crowded and overcrowded metropolis and megalopolis began in the final part of $19^{\text {th }}$ Century. In that time, capitalism dominated European capitals architecture, with larger than ever department stores, shopping arcades and galleries: spaces for exhibition of goods, and also new spaces for urban socialisation (Minca, 2001). The euro-american wealthy people used to pay to see representation of reality, not so much in theatres (were mainly invented stories were represented), but in circuses, zoological gardens and, since Paris 1886, in the Universal Exhibitions. Here there were exhibited both the past and the triumph of modern, always progressing to the future. What people could see there were not invented stories, but reality: well, not exactly reality, but a representation of real reality, as in circuses animals were living and moving, in Exhibitions products were solid. Visitors were seeing a model representation, but so real to persuade of a determined correspondence between model and reality. The Paris Universal Exhibition was in the centre of the city, and in its centre stood a large model of Paris, surrounded by exhibitions coming from the entire productive world, first of all, of course, from the French Empire. And the French visitor had the impression to be present in the real centre of the world. Useless to say that all the European States tried to organise their own Universal Exhibition as soon as possible, in their respective capital city. The effect was not only the amused interest of the visitors, but the diffusion in the European collective imagery of stereotypes which, through spectacularisation, would evoke some larger truth. In the common life, all the visitors were pushed to buy the new products, because they were marvellous, useful, or just because some friend had bought them already: the common mentality changed, and the tendency to consumerism slowly began to sprout.

Today, in all cities, particularly in the global ones, the visitors find a series of exhibition spaces where he can satisfy any desire; if he has not, be sure that some will soon arise. It is hyper-consumerism time, and the panorama of the global cities can be considered as what C. Minca (2001), following and developing T. Mitchell (1988), called world-as-exhibition. About development, the globalisation era is dramatically uneven: growth has been accompanied by exclusion and the Fukushima's market democracy often led to marginalisation. In the 1992 UNCTAD Conference in Rio it has been said that in the world there were about 800 million people excluded from possible progress, and decision was taken to reduce the number to an half. 20 years later the number is has been admitted that the number is evaluated near to a billion. Surely, some of them know about the existence of internet, but does anybody thinks their life has improved thanks to the global communicating facilities? And exclusion phenomena are present at all scales: among different States, inside the States among the Regions, in the Regions between cities and country, inside cities among boroughs, especially in the global ones. Is there a possible link between the growing communication facilities and the mass exclusion from progress? I am afraid there is.
In the ' $60 \mathrm{~s}$, the 3rd World development was shown by brand new iron and steel works; years later, during the ' $90 \mathrm{~s}$, the strong pressure of the WB and IMR imposed cutbacks in social programs. The poor countries became more attractive for foreign investments, and now the 3rd World image is filled with consumer's brand sweatshops. As always happens, capitals are invested where they find more revenue. Then, in more recent years, capitals found that the more productive activity is not material production, but money moving, investing and changing. The old Ponzi scheme become the usual behaviour of the major banks at international level, generating a flood of financial derivate, thus determining the worst world crisis after 1929: officially declared in 2008, this is still remaining as a really global phenomenon. The Lehman Brothers bankruptcy in that year demonstrated that no bank was too big to fall. But the capitalistic financial system is so solid that the worst consequences have not been for the banks, least of all for their directory boards, coming out the crisis with stock options worth millions of dollars.

It is only cold comfort that cyberspace communicating facilities make it easy for Diasporas to interact with their core areas, though living thousands miles away, because this is also facilitating the growth of terrorist groups in Western world. And this answers with the illegal use of drones to kill terrorist chiefs, usually with, unfortunately, some collateral casualties. As usual, technic is neither good nor bad, but just neutral: all depends on the use one does of it.

Some more borders observation: when in the ' 60 s Kennedy moved the frontier to the outer space, he didn't imagine that half a century later a fight could be born at lower level, just in what we usually call the virtual cyberspace, borderless by definition: the use of this can really be evil. In 2010 the Australian journalist J. Assange began to publish US military and diplomatic documents, revealing that US Agencies were illegally gathering information everywhere in the world, with industrial spying activity. Even worst has been discovering in Autumn 2013, thanks to E. Snowden, former dependent of CIA, that all the telephone calls of the world were being intercepted. Billions of these have no interest, but the new that CIA was intercepting the cellular phone of the German Prime Minister had terrible effect: today USA-German relations are still frosted, more than cold.

Yet, I want to finish with a positive border story, happened in Cyprus. The Island is divided in a Greek and a Turkish sector, with a separating belt under UN control (buffer). Anna Casaglia, a young researcher in the Milan University La Bicocca, presented a paper in a Meeting on Borders (Trieste, 2012), showing that the youngsters of both sides were transforming the no men's land in a joyful happening event, named Occupy the buffer zone; some disturb came only by Greek police. My faith in young people is unlimited and, in conclusion, I invite you to join my hope: probably the coming generations will be more able than us in solving boundaries problems.

\section{References}

Agnew J.A.: 1994: The territorial trap: the geographical assumptions of international relations theory. Review of International Political Economy 1, 53-80.

Allen, J. and Hamnett, C., eds, 1995: A shrinking world? Global unevenness and inequality.

Oxford: Oxford University Press and the Open University.

Castells M., 1996, The rise of Network Society, Oxford, Blackwell.

Dell'Agnese E., Geo-graphing: Writing Worlds. In Kevin Cox, M. Low and J. Robinson eds: The Sage Handbook of Political Geography, SAGE Publications Ltd, 2008, pp.439-455. 
The International Archives of the Photogrammetry, Remote Sensing and Spatial Information Sciences, Volume XL-4/W3, 2013 ISPRS/IGU/ICA Joint Workshop on Borderlands Modelling and Understanding for Global Sustainability 2013,

\section{5 - 6 December 2013, Beijing, China}

Dematteis G., Progetto implicito. Il contributo della geografia umana alle scienze del territorio,.Milano, Franco Angeli, 1995.

Farinelli F., 1992, I segni del mondo. Immagine cartografica e discorso geografico in età moderna, Firenze, La Nuova Italia.

Guichonnet P., Raffestin C., Gèographie des frontières, Paris, PUF, 1974

Johnston R.J., Taylor P., Watts M. (eds), (2002), Geographies of Global Change. Malden (MA), pp. 518.

Kuehls, T. 1996: Beyond sovereign territory: the space of ecopolitics. Minneapolis, MN: University of Minnesota Press

Minca C., 2001, Postmodern temptation, in C.Minca ed, Postomodern Geographies, Oxford, Blackwell, pp.196-225

Minghi J., 'Boundary Studies in Political Geography', in Annals of the Association of American Geographers (1963), p.407.

Mitchell T., 1988, Colonizing Egypt, Berkeley, University of California

Press.

Mlinar, Z. 1992: Introduction in Mlinar, Z., editor, Globalization and territorial identities. Aldershot, Aveburys

Newmann D., Paasi H., 1998: Fences and neighbours in the postmodern world: boundary narratives in political geography, in Progress in Human Geography, 22,2 1998, pp.186-207

Oommen, T.K. 1995: Contested boundaries and emerging pluralism. International Sociology, 10.

Sharp, J.P. (1993) 'Hegemony, popular culture and geopolitics: the Reader's Digest and the construction of danger', in Political Geography, 15.

Van Houtun H., 2005, The Geopolitics of Borders and Boundaries, in Geopolitics, n.10.

Shapiro, M.J. and Alker H.R., editors, 1996. Challenging boundaries: global flows, territorial

identities. Minneapolis, University of Minneapolis Press. 